\title{
The impact of social media brand communication on consumer-based brand equity dimensions through Facebook in fast moving consumer goods: The case of Egypt
}

\author{
Heba Sadek \\ Sarah Elwy \\ Arab Academy for Science, Technology \& Maritime Transport, Alexandria, Egypt \\ Mohamed Eldallal \\ Chief Executive Officer at Innovideas, LLC, Egypt
}

\section{Keywords}

Social media, Facebook, CBBE dimensions, Brand equity, FMCG, Egypt context

\begin{abstract}
The purpose of this paper is to examine the impact of firm-created and user-generated social media brand communication on five consumer-based brand equity (CBBE) dimensions through Facebook on the Egyptian fast-moving consumer goods (FMCG) industry.

This paper used quantitative approach, which consists of distributing, collecting, and analyzing large-scale questionnaire survey. Questionnaires were administered personally and electronically distributed. Data were collected from 400 customers based on quota sampling technique to cover the Egyptian population distribution and analyzed by using Structural Equation Modelling (SEM).

The results of our paper showed that firm-created social media brand communication has a significant positive direct impact on only four CBBE dimensions (brand awareness, brand perceived quality, brand associations and brand trust). Whereas user-generated social media brand communication has no significant impact on brand perceived quality, brand loyalty, and brand trust. Additionally, it has been found that usergenerated social media brand communication has a negative impact on brand awareness and brand associations.

This paper adds to the body of knowledge by focusing on the impact of two different types of social media communication (firm-created and user-generated social media brand communication) on 5 CBBE dimensions (brand awareness, brand perceived quality, brand associations, brand loyalty, and brand trust) in new context, which is the Egyptian FMCG industry. On the other hand, this paper provides vital information to the marketing specialists and brand managers to understand how CBBE dimensions could be built via two different types of social media communication.
\end{abstract}

Corresponding author: Heba Sadek

Email addresses for corresponding author: heba_sadek@yahoo.co.uk

First submission received: 25th June 2017

Revised submission received: 30th August 2017

Accepted: 28th September 2017

\section{Introduction}

Social media has evolved as new technological tool, it uses mobile and web-based technologies to generate very interactive and collaborative platforms through which individuals and societies can share, discuss, and amend user-generated content (Kietzmann et al. 2011). This type of media includes diverse outlets such as: social networking sites (SNS), creativity works sharing sites, business networking sites, collaborative websites, etc. (Mangold \& Faulds 2009). In the past few years, SNS has grown rapidly and has become the main media through which people develop their personal network online (Bruno \& Dabrowski 2015). The rapid growth of SNS is not only among individuals and societies but also amongst companies who started using SNS to promote and communicate information about their brands (Bruno \& Dabrowski 2015, Kaplan \& Haenlein 2012).

Social media is considered to be a strong communication channel for brands that seek to connect with their customers and enhance their brand equity (Khalid 2016). Based on the Internet World Stats 
(2017) over than $49 \%$ of the world's population have access to the internet and around 1.86 billion active users use SNS of which 32 million are in Egypt. Therefore, social media has changed the traditional oneway communication to multi-dimensional, two-way and peer-to-peer communication (Berthon et al. 2008). However, it is really important that we differentiate between the two types of social media communication as one is controlled by the firm, whereas the other is independent of the company's control (Bruno \& Dabrowski 2015).

Despite, the fast growth in popularity of social media across consumers and companies, few studies focused on the impact of these two types of social media brand communication on two or maximum three CBBE dimensions (such as: Bruhn, Schoenmueller \& Schafer 2012; Bruno \& Dabrowski 2015). Besides, these previous studies were conducted in European context and in different industries like clothing and mobile network providers. Based on Bruno and Dabrowski (2015), there is a need to further examine the impact of these types of social media in other countries and also in other industries.

Therefore, this paper provides a better understanding by filling the gaps found in the previous studies through answering the following research question: How do firm-created and user-generated social media brand communication impact 5 CBBE dimensions in the Egyptian FMCG via the most popular SNS in Egypt-Facebook. Consequently, we developed a conceptual framework to examine the impact of firm-created and user-generated social media brand communication on brand awareness, brand perceived quality, brand associations, brand loyalty and brand trust on the Egyptian FMCG industry. In Egypt, the household FMCG expenditure is ranked second with value of (US\$27.6bn) which represents almost 34.4\% from the family income (KPMG Africa report 2016, Capmas 2017).

\section{Literature review}

\subsection{Social Media and Facebook}

Social media is becoming an integral part of everyday life for communicating, sharing information and content (Khalid 2016). It has brought revolutionary new ways of interacting, participating, cooperating and collaborating amongst individuals and companies (Bruhn, Schoenmueller \& Schafer 2012). An Integral Part of social media is the user-generated content, which allows people to connect through a "many-to-many", rather than the traditional "one-to-many", communication approach (Prahalad \& Ramaswamy 2004). Among social media platforms, Facebook is the most widely used (Arenas-Gaitan et al. 2013).

In 2017, the population of Facebook exceeded the population of China making it the largest "virtual" country in the world (Schwab 2017). Egypt is considered a regional leader in MENA in the number of Facebook users covering $26.4 \%$ of the total number of users in the region (E-marketing Egypt platform 2016). Furthermore, SNS particularly Facebook is not only used among customers, but it also provides businesses with a relatively quick and low-cost method of connecting with customers (Fischer \& Reuber 2011). Traditionally, marketers viewed value as something created within the firm and then offered to customers who decide their willingness to pay (Vargo \& Lusch 2004). However, value creation is now becoming a process of co-creation involving both firm and customer through an ongoing dialogue of experiences and transparent communications (Saarijärvi, H., Kannan, P.K. \& Kuusela, H 2013).

\subsection{Firm Created and User generated social media brand communication}

For the past few years, social network services (SNS) have become very popular for millions of users, becoming their daily practices (Boyd \& Ellison 2007). According to Shi et al. 2010 this wide spread and increasing influence on society increased the commercial value of SNS. As a result, a firm's SNS page became an essential part of its business and an essential tool for many service functions toward customers (Bruno \& Dabrowski 2015). There are many benefits that a firm can achieve through its SNS page such as (1) an additional communication channel and a link with its devoted users (Jang et al. 2008), (2) a cost reduction form that can be used in customer retention and customer service, and (3) a tool to increase sales, customer satisfaction, and brand image (Banks \& Daus 2002).

However, in the participatory context of SNS, firms do not have the monopoly of brand-related communications anymore. The emergence of user generated social media brand communication has caused a paradigm shift from the publisher to the user-centric media model (Christodoulides, Jevons \& Bonhomme 2012). According to Christodoulides et al. 2012, user generated social media brand 
communication can be stated as any material that is created outside professional practices, and have been published online. User generated social media brand communication can have various forms; the most common being consumer-produced reviews and recommendations (Mũniz \& Schau 2007). Recent studies (e.g., Goh, Heng \& Lin 2013, Bruno \& Dabrowski 2015) highlight the persuasive and convincing power of user generated social media brand communication over marketer-generated content. Since SNS are really dynamic and easy to use consumers are becoming pivotal authors of brand stories (Gensler et al. 2013). In this paper, firm-created and user-generated social media brand communications are considered to be independent variables and are expected to positively impact the CBBE dimensions.

H1: Firm-created social media brand communication has a significant positive direct impact on $5 \mathrm{CBBE}$ dimensions.

H2: User-generated social media brand communication has a significant positive direct impact on 5 CBBE dimensions

\subsection{Social media brand communication impact on CBBE dimensions}

Models of the CBBE construct have evolved over time, and have been a subject of controversy. Aaker (1991) defined CBBE based on a set of dimensions, which include brand awareness, brand associations, perceived quality, and brand loyalty. In addition to other proprietary brand assets such as competitive advantage. Keller's (1993) original model of CBBE involved two dimensions, brand awareness and brand image. Brand equity from this perspective occurs when a consumer is familiar with the brand and holds some favourable, strong, and unique brand associations in memory. However, Lassar et al. (1995) argue for a five-factor conceptualization comprised of performance, social image, value, trustworthiness, and attachment. Moreover, Yoo et al. (2000) stated that the CBBE dimensions include brand perceived quality, brand loyalty, and brand associations combined with brand awareness. Recently, few studies involved trust in their CBBE dimensions due to its importance. For example, Atilgan et al. (2009) included trust as possible CBBE dimension, which includes brand associations, perceived quality, loyalty and trust. Kimpakorn and Tocquer (2010) mentioned that CBBE dimensions include brand awareness, brand perceived quality, brand differentiation, brand associations, brand trust and brand relationships. Bruno and Dabrowski (2015) indicated that the CBBE dimensions comprise brand loyalty, brand awareness/associations and brand perceived quality.

From the previous studies, it has been shown that numerous researchers have suggested different CBBE dimensions that can be linked to a brand. These different CBBE dimensions are interrelated. In other words, there are interrelationships that exist among the CBBE dimensions (Yoo et al. 2000; Atilgan et al. 2005; Tong \& Hawley 2009; Xu \&Chan 2010; Torres et al. 2015). Based on the literature, the common dimensions in all models are the usage of one or more dimensions of Aaker's model (1991). Particularly, the widespread dimensions include brand awareness, brand perceived quality, brand associations and brand loyalty. Therefore, the researchers examined the effect of these dimensions (brand awareness, brand associations, brand perceived quality and brand loyalty) in addition to brand trust due to its vital role as a risk-reducing tool that helps reassure customers (De chernatony \& Dall'Olmo Riley 1999; De chernatony \& Cottam 2006). The five CBBE dimensions are presented as follows:

\subsubsection{Brand awareness}

Brand awareness is the ability of a buyer to identify and recall that a brand belongs to a particular product category (Aaker 1991; Atilgan et al. 2005). According to Vrontis and Papasolomou (2007), a powerful brand benefits from a high level of consumer brand awareness. Buyers are exposed to a lot of products from different brands; hence the brands that customers are familiar with are usually taken into consideration in the pecking order. The most favoured brands are those that are easily recognizable or identifiable, categorised and eventually purchased (Baldauf et al. 2003). Previous researches have reported that brands have a good chance of being incorporated into the customer's consideration set by using brand communication to improve brand equity. Thus, increasing the probability of a brand choice will lead to a shorter decision-making process and turning that choice into a habit (Yoo et al. 2000). According to Hutter et al. (2013), there is a strong relationship between the consumers' engagement with a Facebook brand fan page and their brand awareness. Therefore, we assume that there is a positive impact of firmcreated and user-generated social media brand communications on brand awareness. 
H1a: Firm-created social media brand communication has a significant positive direct impact on Brand Awareness.

H2a: User-generated social media brand communication has a significate positive direct impact on Brand Awareness.

\subsubsection{Brand Perceived quality}

Brand Perceived quality refers to the perception of the superiority of the product compared to others in the same category or close substitutes (Yoo et al 2000). As explained by Baldauf et al. (2003), the quality of a product is a very important aspect that enables the firm to achieve competitiveness. According to Hamann et al. (2007), branding contributes greatly to assure customers of the quality of products. Consumers generally perceive extremely advertised brands as higher quality brands (Yoo et al 2000). Therefore, in the SNS, we assume that consumers will perceive the quality of the firm-created social media brand communication with the quality of the brand itself similarly to traditional media. Moreover, Li and Bernoff (2011) mentioned that user-generated social media brand communication has become an integral source of information to consumers. It complements or even substitutes other forms of firm-to-consumer and consumer-to-consumer about product quality. Riegner (2007) stated that online user generated brand communication is an important mean whereby customers can get information about products or service quality. Consequently, we assume that consumers will interpret user generated communication to be derived from other peers' satisfaction of product and brand quality, therefore, influencing their own perceptions of brand quality. Thus, we assume that social media brand communication including firmcreated and user-generated have a positive impact on brand perceived quality.

H1b: Firm-created social media brand communication has a significant positive direct impact on Brand Perceived Quality.

H2b: User-generated social media brand communication has a significate positive direct impact on Brand Perceived quality.

\subsubsection{Brand associations}

Brand associations refer to the relative strength of a consumers' positive feelings towards the brand (Lassar et al. 1995). It has been argued by some researchers that when the customers' experience of a brand is positive, the brand becomes stronger (Bruno \& Dabrowski 2015). Brand associations may reflect the product features and other aspects independent of the product (Chen 2001). Particularly, in consumer goods, brand associations are grouped in the form of product related attributes such as brand performances and also non-product related attributes such as brand personality, user profile, and country of origin (Aaker 1991; Keller 2003; Netemeyer et al. 2004; Gronroos 2007). Based on, Bruhn et al. (2012), individuals' perception of brands in the context of social media brand communication positively influences brands identity. Additionally, Bruno and Dabrowski (2015) indicated that social media brand communication help build unique and positive associations in the consumers' mind. Thus, we assume that there is a positive impact of firm-created and user-generated social media brand communications on brand associations.

H1c: Firm-created social media brand communication has a significant positive direct impact on Brand Associations.

H2c: User-generated social media brand communication has a significant positive direct impact on Brand Associations.

\subsubsection{Brand loyalty}

Brand loyalty is the strong commitment by consumers to repurchase their preferred product or service on a continuous basis in the future in spite of influences (Atilgan et al. 2005). When a customer is loyal they are not affected by the strategies that are employed by competitors to attract (Tong \&Hawley 2009). Unlike the other aspects of brand equity, brand loyalty develops from actual buying and usage of the product or brand (Baldauf et al. 2003). It is also important to mention that brand loyalty is based on customers' interactions with the company (Palmatier et al. 2007). This interaction can be in the form of firm created social media brand communication or user-generated social media brand communication. Based on Khalid (2016), the firm-created social media brand communication has a significant positive 
impact on brand loyalty. Differently from firm-created social media brand communication, user generated brand communication is thought to be unbiased because other consumers adopt the message as credible and trustworthy (Christodoulides et al. 2012). Thus, it's considered a validator of a brand's attractiveness. Therefore, we assume that social media brand communications (firm-created and user-generated) have a positive impact on brand loyalty.

H1d: Firm-created social media brand communication has a significant positive direct impact on Brand Loyalty.

$\mathrm{H} 2 \mathrm{~d}$ : User-generated social media brand communication has a significant positive direct impact on Brand Loyalty.

\subsubsection{Brand trust}

Brand trust is defined as the willingness of a buyer to rely on the capability of a brand to fulfil the communicated functions and features, which is measured by the brand's ability to deliver its promises (Kimpakorn \& Tocquer 2010). Brand trust is a part of customer's relationship with the brand (Atilgan et al. 2009). Based on Lassar et al. (1995); Luk and Yip (2008); Rios and Riquelme (2008); Rauyruen (2009); Yacout and Elsahn (2011) and Kumar et al. (2013), brand trust has been conceptualized as one of the CBBE dimensions affecting the overall brand equity. These previous studies mentioned that trust is derived from the customer interaction with the brand. Few studies have examined the impact of social media brand communications on brand trust. Based on Khalid (2016) the firm-created social media brand communication shows positive influence on brand trust. He mentioned that the most important point of this finding is the source of reliability. Moreover, he stated that customers can rely deeply on the firm created contents, friends, and other consumers regarding the brand. Therefore, we assume that firmcreated and user-generated social media brand communications have a positive impact on brand trust.

H1e: Firm-created social media brand communication has a significant positive direct impact on Brand Trust.

H2e: User-generated social media brand communication has a significant positive direct impact on Brand Trust.

This paper helps to fill the gaps found in the previous studies by examining the impact of social media brand communications (firm-created and user-generated) on the five CBBE dimensions as shown in figure (1) in the Egyptian FMCG industry.

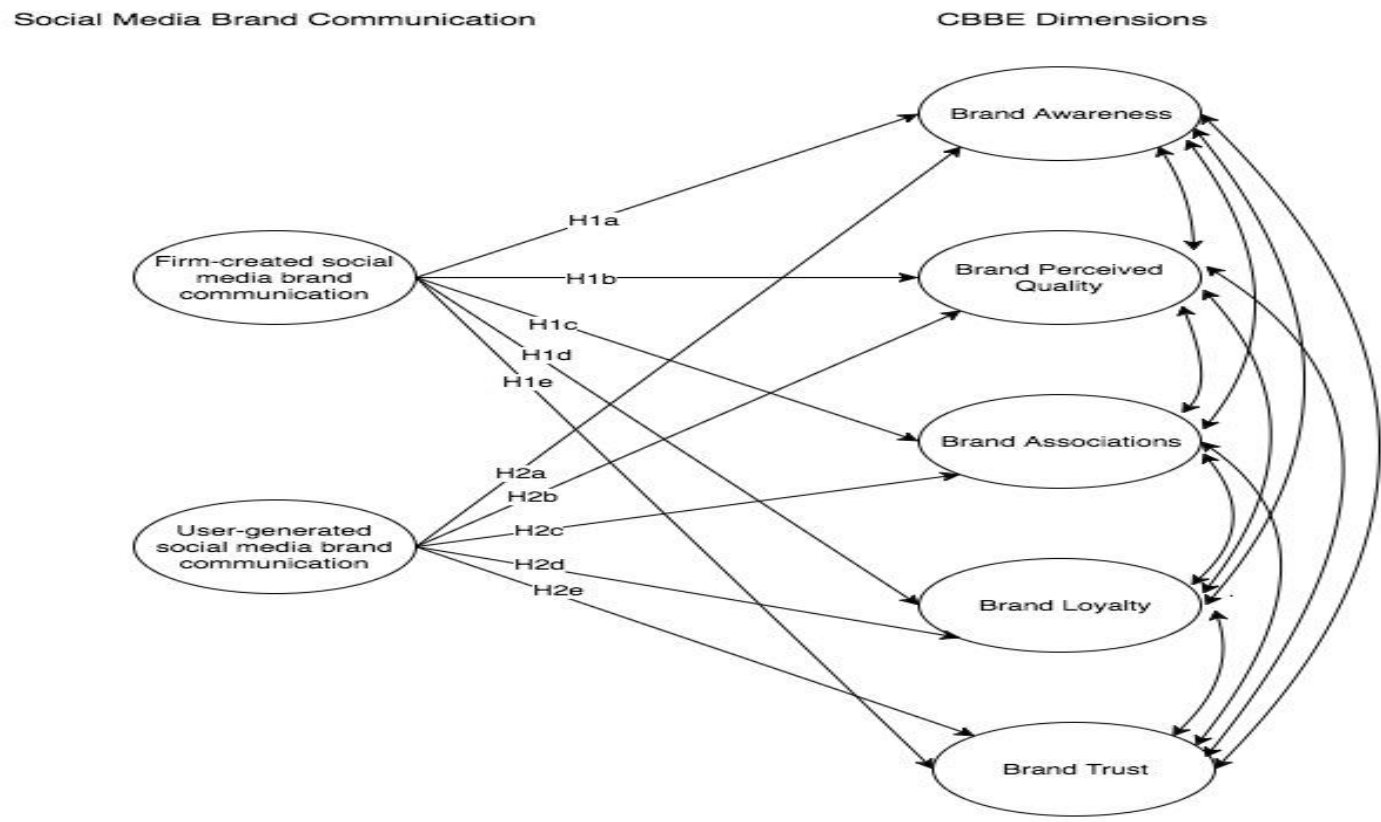

Figure (1): proposed model 


\section{Methodology}

A quantitative approach was conducted, which consists of distributing, collecting and analyzing large-scale questionnaire survey. Questionnaires were administered personally and electronically distributed to test the research hypotheses. The items of each research variable were adopted from the literature and adjusted to the (FMCG) industry. For the brand awareness, six items were adopted from Yoo et al. (2000) and Kumar et al. (2013). For brand perceived quality, ten items were adopted from Yoo et al. (2000) and Buil et al. (2013). For brand associations, ten items were adopted from Yoo et al. (2000) and Tong and Hawley (2009). For brand loyalty, nine items were adopted from Yoo et al. (2000) and Tong and Hawley (2009). For brand trust, ten items were adopted from Dimitriadis and Kyrezis (2008). For firmcreated and user-generated social media brand communication four items were adopted from Magi (2003); Tsiros et al. (2004); Bruhn et al. (2012) and Bruno and Dabrowski (2015). A quota sampling technique was used because this paper was not able to gain hold on a sampling frame. The quota sampling comprises two steps. The first step was to select the regions that cover all Egypt. Based on Central Agency for Public Mobilization and Statistics, Egypt CAPMAS (2017), there are a total of seven major regions, each one consists of number of cities that cover the Egyptian population as shown in the following table:

Table (1): The seven major areas that cover Egypt

\begin{tabular}{|c|c|c|}
\hline Region \# & Region Name & Governorates \\
\hline 1 & Greater Cairo & Cario, Giza, Qalyobeya \\
\hline 2 & Alexandria & Alexandria, Matrouh, Behera \\
\hline 3 & Delta & Dakalia, Kafr al Sheikh, Ghahrbya, Monofeya, Demietta \\
\hline 4 & Suez Canal & Portsaid, Suez, Ismailia, North Sinai, South Sinai, Sharkia \\
\hline 5 & Northern Upper Egypt & Beniseuf, Menya, Fayoum \\
\hline 6 & Asyut & Asyut, El Wadi Al Gdeed \\
\hline 7 & Southern Upper Egypt & Sohag, Qena, Luxor, Aswan, Red Sea \\
\hline
\end{tabular}

After the selection of regions, the researchers conducted the second step, which was to select the respondents from each region respectively to its percentage of the Egyptian population as shown in table (2). The researchers were able to distribute the questionnaire electronically using google forums to reach more people all over Egypt via sending direct messages with the Survey link to respondents through Facebook messages and also by sharing the link on some of the Facebook groups that are targeting respondents in different regions. Besides on various days of the week, the researchers visited some of those regions and began to approach the respondents. Respondents were approached and asked if they would like to participate in a research project. Those who agreed were given a questionnaire to fill out. The researchers shared the shorten URL survey link to target respondents in different regions to be able to measure the conversion rate. The conversion rate was $30.5 \%$ as 297 was completed out of 973 checked survey. The remaining 103 were collected face to face. The total questionnaires were 400, which were analyzed by using the (SEM), AMOS 22.

Table (2) illustrates the major regions the percentage of regions' population, the number of respondents and their percentage in each region.

\begin{tabular}{|c|c|c|c|c|}
\hline $\begin{array}{l}\text { Region } \\
\#\end{array}$ & Region Name & Governorates & $\begin{array}{c}\% \text { of } \\
\text { population }\end{array}$ & Respondents \\
\hline 1 & Greater Cairo & Cario, Giza, Qalyobeya & 24.80 & 99 \\
\hline 2 & Alexandria & Alexandria, Matrouh, Behera & 12.50 & 50 \\
\hline 3 & Delta & $\begin{array}{l}\text { Dakalia, Kafr al Sheikh, Ghahrbya, } \\
\text { Monofeya, Demietta }\end{array}$ & 21.70 & 86 \\
\hline 4 & Suez Canal & $\begin{array}{l}\text { Portsaid, Suez, Ismailia, North Sinai, South } \\
\text { Sinai, Sharkia }\end{array}$ & 10.82 & 44 \\
\hline 5 & $\begin{array}{c}\text { Northern Upper } \\
\text { Egypt }\end{array}$ & Beniseuf, Menya, Fayoum & 12.85 & 52 \\
\hline 6 & Asyut & Asyout, El Wadi al Gdeed & 5.11 & 20 \\
\hline 7 & Southern Upper & Sohag, Qena, Luxor, Aswan, Red Sea & 12.22 & 49 \\
\hline
\end{tabular}




\begin{tabular}{|c|c|c|c|c|}
\hline & Egypt & & & \\
\hline & & Totals & $100 \%$ & 400 \\
\hline
\end{tabular}

\section{Results and analysis}

Before testing the hypotheses, a number of tests were conducted such as: reliability analysis, validity of scales, and measurement model fit indices.

\subsection{Reliability analysis}

Testing the reliability is vital as it shows the extent to which a scale produces consistent result if measurements are made repeatedly. The following table (3) summarizes the results of Cronbach's alpha coefficient

Table (3) Reliability analysis

\begin{tabular}{|c|c|}
\hline Variables names & Cronbach's alpha coefficient \\
\hline Firm-created social media brand communication & 0.877 \\
\hline User-generated social media brand communication & 0.872 \\
\hline Brand awareness & 0.860 \\
\hline Brand perceived quality & 0.901 \\
\hline Brand associations & 0.851 \\
\hline Brand loyalty & 0.892 \\
\hline Brand trust & 0.890 \\
\hline
\end{tabular}

From the above table, Cronbach's alphas values ranged between 0.851 and 0.901 , which indicate an acceptable level of scale reliability for theory testing research (Nunnally and Bernstein, 1994). This means that each scale will produce consistent result if measurements are made repeatedly.

\subsection{Validity of scales}

Validity of scales was tested through explanatory and confirmatory factor analysis.

\subsubsection{Explanatory factor analysis}

Explanatory factor analysis using the principal component analysis was used to examine the validity of the social media brand communication (firm-created social media brand communication and user generated social media brand communication) and CBBE dimensions (brand awareness, brand perceived quality, brand associations, brand loyalty and brand trust).For researchers using factor analysis, consider factor loadings of 0.30 or more significant for sample sizes of 350 or greater will be suitable(Hair et al., 2010).In this paper, the factor loading of each item of the research variables were above the recommended level demonstrating the significant contribution of the items in measuring their variables. Moreover, the explanatory factor analysis was used to detect the unidimensionality of each construct. Unidimensionality is an evidence that a single construct underlies a set of measures (Anderson and Gerbing, 1988). Based on Hair et al. (2010), the unidimensionalty was expressed by the Average Variance Extracted (AVE) that should be greater than $50 \%$. In this paper, the researchers deleted some items to enhance the quality of measures and to be able to identify the unidimensionality (for example, the researchers used nine items instead often in measuring brand perceived quality. In addition, seven items were used instead of ten in measuring brand associations and finally nine items were used instead of ten in measuring brand trust).

\subsubsection{Confirmatory factor analysis}

Confirmatory factor analysis using the maximum likelihood estimates was used to test whether measures of a construct are consistent with a researcher's understanding of the nature of that construct. Thus, the objective of confirmatory factor analysis is to test whether the data fit a hypothesized measurement model (Hair et al., 2010).

The following table summarizes the research variables, their items, explanatory factor analysis (EFA), confirmatory factor analysis (CFA)and the AVE of each variable. 
Table (4): The research variables, their items, explanatory factor analysis (EFA), confirmatory factor analysis (CFA) and the AVE of each variable.

\begin{tabular}{|c|c|c|c|c|}
\hline Variables & Items & EFA & CFA & AVE \\
\hline \multirow[t]{4}{*}{$\begin{array}{l}\text { Firm-created } \\
\text { social media }\end{array}$} & $\begin{array}{l}\text { I am satisfied with the company's social media communications } \\
\text { conducted via Facebook for this brand }\end{array}$ & 0.899 & 0.886 & \multirow{4}{*}{$73.331 \%$} \\
\hline & $\begin{array}{l}\text { The level of the company's social media communications conducted } \\
\text { via Facebook for this brand meets my expectations }\end{array}$ & 0.857 & 0.824 & \\
\hline & $\begin{array}{l}\text { The company's social media communications conducted via Facebook } \\
\text { for this brand are very attractive }\end{array}$ & 0.878 & 0.824 & \\
\hline & $\begin{array}{l}\text { The company's social media communications conducted via Facebook } \\
\text { for this brand perform well, when compared with the social media } \\
\text { communications of other companies }\end{array}$ & 0.787 & 0.715 & \\
\hline \multirow[t]{4}{*}{$\begin{array}{l}\text { User-generated } \\
\text { social media }\end{array}$} & $\begin{array}{l}\text { I am satisfied with the content generated on Facebook by other users } \\
\text { about this brand }\end{array}$ & 0.826 & 0.748 & \multirow{4}{*}{$72.393 \%$} \\
\hline & $\begin{array}{l}\text { The level of the content generated on Facebook by other users about } \\
\text { this brand meets my expectations }\end{array}$ & 0.867 & 0.863 & \\
\hline & $\begin{array}{l}\text { The content generated on Facebook by other users about this brand is } \\
\text { very attractive }\end{array}$ & 0.839 & 0.862 & \\
\hline & $\begin{array}{l}\text { The content generated on Facebook by other users about this brand } \\
\text { performs well, when compared with other brands }\end{array}$ & $\overline{0.870}$ & 0.801 & \\
\hline \multirow[t]{2}{*}{ Brand awareness } & I am aware of this brand. & 0.728 & 0.671 & \multirow{6}{*}{$62.299 \%$} \\
\hline & $\begin{array}{l}\text { When I think of FMCG, this brand is one of the brands that come to } \\
\text { mind. }\end{array}$ & 0.574 & 0.484 & \\
\hline \multirow{4}{*}{ Brand awareness } & I can recognize this brand among other competing brands. & 0.799 & 0.749 & \\
\hline & I know this brand very well. & 0.845 & 0.769 & \\
\hline & This brand is very familiar to me. & 0.882 & 0.899 & \\
\hline & I can quickly recall this brand. & 0.866 & 0.816 & \\
\hline \multirow{10}{*}{$\begin{array}{l}\text { Brand perceived } \\
\text { quality }\end{array}$} & Compared to other brands, this brand is of high quality. & 0.720 & 0.680 & \multirow{10}{*}{$56.620 \%$} \\
\hline & This brand is the best brand in the FMCG. & 0.601 & 0.514 & \\
\hline & This brand consistently performs better than all other brands. & 0.784 & 0.752 & \\
\hline & I can always count on this brand for consistent high quality. & 0.763 & 0.738 & \\
\hline & This brand offers products with excellent features. & 0.820 & 0.812 & \\
\hline & I believe this brand offers superior products in every way. & 0.777 & 0.754 & \\
\hline & The overall quality of the products provided by this brand is excellent. & 0.741 & 0.732 & \\
\hline & The quality of the products provided at this brand is impressive. & 0.754 & 0.691 & \\
\hline & The products provided by this brand are of high standard. & 0.791 & 0.745 & \\
\hline & This brand appears to be of poor quality. & & & \\
\hline \multirow{8}{*}{$\begin{array}{l}\text { Brand } \\
\text { associations }\end{array}$} & Some characteristics of this brand come to my mind quickly. & 0.592 & 0.480 & \multirow{8}{*}{$53.530 \%$} \\
\hline & I remember the logo of this brand. & 0.710 & 0.657 & \\
\hline & I have difficulty in imagining this brand in my mind. & & & \\
\hline & This brand has a strong personality. & 0.823 & 0.782 & \\
\hline & I have a clear image of the type of person who would use this brand. & & & \\
\hline & This brand has a strong image. & 0.816 & 0.790 & \\
\hline & This brand has a favorable image. & 0.832 & 0.824 & \\
\hline & $\begin{array}{l}\text { The intangible attributes of this brand are reason enough to use this } \\
\text { brand. }\end{array}$ & 0.652 & 0.600 & \\
\hline
\end{tabular}




\begin{tabular}{|c|c|c|c|c|}
\hline & \multirow{2}{*}{$\begin{array}{l}\text { This brand is good value for money. } \\
\text { This brand has a unique image in my mind compared to other } \\
\text { competing brands }\end{array}$} & \multirow[b]{2}{*}{0.656} & \multirow[b]{2}{*}{0.588} & \\
\hline & & & & \\
\hline \multirow[t]{9}{*}{ Brand loyalty } & I consider myself to be loyal to this brand. & 0.797 & 0.747 & \multirow{9}{*}{$54.202 \%$} \\
\hline & This brand is my first choice when I am buying FMCG products & 0.767 & 0.673 & \\
\hline & I will not switch to other brands if this brand is available. & 0.666 & 0.552 & \\
\hline & $\begin{array}{l}\text { I intend to continue using this brand's products in the upcoming } \\
\text { years. }\end{array}$ & 0.694 & 0.678 & \\
\hline & I recommend this brand to my friends and relatives. & 0.807 & 0.769 & \\
\hline & $\begin{array}{l}\text { I will continue to be a customer of this brand even if it reasonably } \\
\text { raises its price. }\end{array}$ & 0.692 & 0.635 & \\
\hline & I regularly use this brand. & 0.682 & 0.648 & \\
\hline & I am proud to use this brand. & 0.755 & 0.771 & \\
\hline & I prefer this brand to other brands. & 0.750 & 0.685 & \\
\hline \multirow[t]{10}{*}{ Brand trust } & This brand considers my needs and wishes as very important. & & & \multirow{10}{*}{$54.215 \%$} \\
\hline & This brand would not do anything against my interests. & 0.627 & 0.575 & \\
\hline & This brand never declares anything that is not valid. & 0.718 & 0.681 & \\
\hline & This brand is always honest to me. & 0.779 & 0.762 & \\
\hline & This brand has the ability to meet its promises. & 0.831 & 0.791 & \\
\hline & This brand can properly handle my complaints. & 0.665 & 0.591 & \\
\hline & This brand is remarkably expert in its field. & 0.565 & 0.547 & \\
\hline & I never doubt this brand's promises. & 0.814 & 0.759 & \\
\hline & This brand behaves consistently. & 0.751 & 0.705 & \\
\hline & This brand keeps its promises. & 0.828 & 0.837 & \\
\hline
\end{tabular}

Note: The shaded rows represent the deleted items to enhance the quality measures

We included all independent and dependent latent variables in one multifactorial CFA model. This model shows a satisfactory fit to the data. As shown in the following table (5), The $\boldsymbol{x}^{2} / \mathrm{df}$ value was 3.427, the Comparative Fit Index (CFI) value was 0.812, The Goodness of Fit Index (GFI) was 0.791 and the Average Goodness of Fit Index (AGFI) value was 0.701. To test the hypothesis, we used SEM in AMOS 22. The $\boldsymbol{x}^{2} / \mathrm{df}$ value was 2.869, the CFI value was 0.886 , the GFI was 0.789 and the AGFI value was 0.744 . All the values were within the range of the permitted threshold (Hair et al., 2010).

Table (5): Model Fit Indices

\begin{tabular}{|l|l|l|l|l|}
\hline Model & $\boldsymbol{x}^{\mathbf{2} / \mathbf{d f}}$ & CFI & GFI & AGFI \\
\hline $\begin{array}{c}\text { The measurement } \\
\text { model }\end{array}$ & 3.427 & 0.812 & 0.791 & 0.701 \\
\hline \multicolumn{1}{|c|}{ SEM model } & 2.869 & 0.862 & 0.789 & 0.744 \\
\hline $\begin{array}{l}\text { The best result } \\
\text { according to Hair } \text { et al., } \\
\text { (2010) }\end{array}$ & $\begin{array}{l}\text { Not more than 5, } \\
\text { (closer to } 1 \text { is } \\
\text { better) }\end{array}$ & $\begin{array}{l}\text { Range from 0 to } 1 \\
\text { (Closer to 1 is } \\
\text { better) }\end{array}$ & $\begin{array}{l}\text { Range from 0 to } \\
1 \text { (Closer to 1 is } \\
\text { better) }\end{array}$ & $\begin{array}{l}\text { Range from 0 to 1 } \\
\text { (Closer to 1 is } \\
\text { better) }\end{array}$ \\
\hline
\end{tabular}

From the above table, it has been showed that the $\boldsymbol{x}^{2} / \mathrm{df}, \mathrm{CFI}$, GFI and AGFI for the proposed model indicate that this model is acceptable.

\subsection{Testing hypotheses}

The AMOS output for the model parameter estimates is presented in table (6). Based on Hair et al. (2010), any number of a critical ratio above 1.96 or P-value less than 0.05 is considered to be significant in the model. 
Table (6): The Unstandardized Estimate, Standardized estimate, SE, CR, P-value and the result of the direct effects

\begin{tabular}{|c|c|c|c|c|c|c|}
\hline & $\begin{array}{l}\text { Unstandardized } \\
\text { estimate }\end{array}$ & $\begin{array}{l}\text { Standardized } \\
\text { estimate }\end{array}$ & SE & CR & P Value & Results \\
\hline BA $<--$ FC & 0.355 & 0.433 & 0.058 & 6.078 & $* * *$ & $\mathrm{~S}$ \\
\hline BPQ <--- FC & 0.219 & 0.305 & 0.056 & 3.947 & $* * *$ & $\mathrm{~s}$ \\
\hline BASS <-- FC & 0.341 & 0.429 & 0.063 & 5.440 & $* * *$ & $S$ \\
\hline BL <-- FC & 0.094 & 0.117 & 0.057 & 1.659 & 0.097 & N.S \\
\hline BT <--- FC & 0.190 & 0.247 & 0.056 & 3.365 & $* * *$ & $\mathrm{~s}$ \\
\hline BA <-- UG & -0.263 & -0.314 & 0.058 & -4.541 & $* * *$ & N.S \\
\hline BPQ <--- UG & 0.010 & 0.014 & 0.052 & 0.193 & 0.847 & N.S \\
\hline BASS <--- UG & -0.199 & -0.245 & 0.059 & -3.399 & $* * *$ & N.S \\
\hline BL <--- UG & 0.033 & 0.040 & 0.056 & 0.583 & 0.560 & N.S \\
\hline BT <--- UG & 0.016 & 0.020 & 0.056 & 0.284 & 0.777 & N.S \\
\hline
\end{tabular}

Notes: ${ }^{* * *}$ is significant at 0.001 S: Supported hypotheses and N.S: Not supported

The obtained statistics indicate that all path coefficients results appeared to be significant except the following paths: the path coefficient from firm-created social media brand communication to brand loyalty, user-generated social media brand communication to brand perceived quality, user-generated social media brand communication to brand loyalty and user-generated social media brand communication to brand trust. All these paths were found insignificant as the P- Values are 0.097, 0.847, 0.560 and 0.777 respectively. Their P-Values are greater than 0.05 , which indicates the insignificant paths.

The first hypothesis, which generally states that: "the firm-created social media brand communication has a significant positive direct effect on CBBE dimensions" was partially supported. It has been found that firm-created social media brand communication has a significant positive direct effect on brand awareness, brand perceived quality, brand associations and brand trust. This result indicates the importance of firm-created social media in creating awareness, in mirroring the brand quality, in building associations and building trusty relationships towards the brand. Additionally, it has been found that the firm created social media has the strongest impact on brand awareness with a standardized estimate of 0.433 . However, the firm-created social media brand communication has no impact on brand loyalty. This lack of impact is based on the Egyptian customers in the FMCG industry, for them brand loyalty may be built based on other factors such as the brand place, the brand price, the product features or other communication channels such as the face-to-face communication, T.V advertising, etc.

The second hypothesis, which generally stated that: "user-generated social media brand communication has a significant positive direct impact on CBBE dimensions" was not supported. It has been found that user-generated social media brand communication has no direct impact on brand perceived quality, brand loyalty and brand trust. Moreover, it has been found that there is a significant negative impact on brand awareness and brand associations. This result indicates that in FMCG, consumers don't rely on user-generated social media brand communication. In addition, there is a negative impact in creating awareness and building associations. When the user generated social media increases, the customers' awareness towards the brand decreases as they skip the user content due to the large volume of posts. Furthermore, the brand associations are negatively affected by user generated brand communications since most of the Egyptian consumers only post online when they are having a bad experience or want to deliver a complaint. After analyzing the research hypotheses, the final model is presented in Figure (2). 


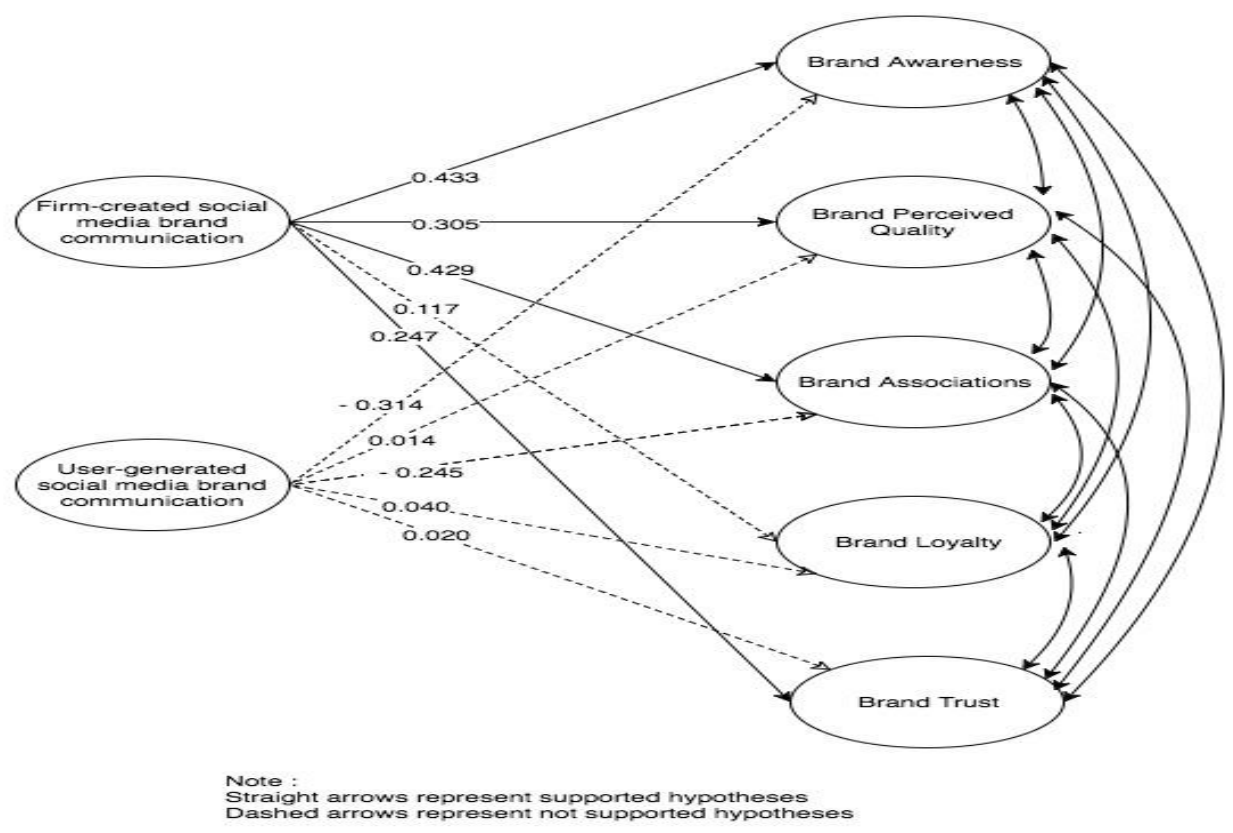

Figure: Final model (2)

\section{Conclusion}

In this paper, a model was proposed in order to provide insights into the degree of impact that the firm-created and user-generated social media brand communications can have on the five CBBE dimensions. Two main hypotheses were tested and the results were as follows: first, firm-created social media impact positively brand awareness, brand perceived quality, brand associations and brand trust. These findings were supported by the previous studies such as Bruhn et al. (2012), Hutter et al. (2013), Bruno and Dabrowski (2015) who mentioned the strong impact of firm-created social media on building brand equity. Additionally, the results showed that firm-created social media didn't have any impact on brand loyalty, which mismatches with the previous study of Khalid (2016) who indicated the great importance of firm-created social media on building brand loyalty.

The second hypothesis was designed to measure the user-generated social media impact on the same 5 CBBE dimensions. By testing our hypothesis, we found out that the user-generated social media's impact on the 5 CBBE dimensions was not supported ( 3 of them totally were not supported and the other two are negatively impacted which defies our hypothesis). These findings mismatch the previous studies such as Riegner (2007), Christodoulides et al. (2012), Hutter et al. (2013), Bruno and Dabrowski (2015) who mentioned the crucial role of user-generated social media on the different CBBE dimensions. The differences in the previous studies can be explained as the earlier studies were done in different countries on different industries. Additionally, the previous researchers did not test the effect of social media brand communication on brand trust so there was no basis for the comparison. Moreover, a logical explanation might be found concerning the impact of user-generated, which is due to the nature of the Egyptian customers as people here tend to always question the content published by other users on social media networks they usually think of it as fake or a part of a battle between competitors.

To conclude, this paper adds to the body of knowledge by examining these two different types of social media brand communications (firm-created and user generated social media brand communications) on 5 CBBE dimensions in the Egyptian FMCG industry. Furthermore, it provides useful insights to marketing managers, particularly in the FMCG by directing them to further invest in firm created social media and pay less attention to the user generated content in order to build brand equity. Thus, enhanced and better decisions linked to the usage of social media could be practiced to stand high in the crowd with high brand equity. 


\section{Limitations \& directions for future research}

This paper used quota sampling, which is a non-probability sampling technique due to the lack of sampling frame. However, the researchers tried to reduce bias and to increase the level of generalizability by selecting respondents from all over Egypt. In other words, from the seven regions in Egypt and according to their population percentage. Like many other developing countries, Egypt shows vital interregional differences. Future research could examine the differences between two or more regions and make a comparison study. Additionally, cross-sectional data were used in this paper. So, Future research can collect longitudinal data. Also, since this paper was conducted in the Egyptian FMCG; a replication can be done within other industries because the impact of the different types of social media brand communication on the CBBE dimensions may vary from one industry to another. Moreover, the main focus of this paper was on the firm created social media and user generated social media brand communications, other communication tools could be tested such as the role of influencers on building brand equity and other communication tools (such as: TV, radio, book media). Not only media tools but also future research can focus on some extended marketing mix elements that can contribute on building brand equity (such as distribution channels, price or product).

\section{References}

Aaker, D. (1991), Measuring Brand Equity: Capitalizing on the Value of a Brand Name, The Free Press, New York, NY

Anderson, J.C., \& Gerbing, D.W. (1988). Structural equation modeling in practice: a review and recommended two-step approach. Psychological Bulletin, Vol.103 No.3 pp. 411-423.

Arenas-Gaitan, J., Rondan-Cataluña, F.J. \& Ramírez-Correa, P.E. (2013), “Social identity, electronic wordof-mouth and referrals in social network services", Kybernetics, Vol. 42 No. 8, pp. 1149-1165.

Atilgan, E., Akinci, S., Aksoy, S., \& Kaynak, E. (2009). Customer-based brand equity for global brands: A multinational approach. Journal of Euromarketing, Vol.18 No.2, 115-132.

Atilgan, E., Aksoy, S. \& Akinci, S. (2005), "Determinants of brand equity: a verification approach in the beverage industry in Turkey", Marketing Intelligence \& Planning, Vol. 23 No. 3, pp. 237-248.

Baldauf, A., Cravens, K.S. \& Binder, G. (2003), "Performance consequences of brand equity management evidence from organizations in the value chain", Journal of Product and Brand Management, Vol. 12 No. 4, pp. 220-236.

Banks, D. \& Daus, K. (2002). Customer. Community: Unleashing the Power of Your Customer Base. Jossey-Bass, San Francisco.

Berthon, P.R., Pitt, L. and Campbell, C. (2008), "Ad lib: when customers create the ad", CA Management Review, Vol. 50 No. 4, pp. 6-31.

Boyd, D. M. and Ellison, N. B. (2007). Social network sites: Definition, history, and scholarship. Journal of Computer-Mediated Communication, Vol.13 No.1, pp. 210-230.

Bruhn, M., Schoenmueller, V. and Schäfer, D.B. (2012), “Are social media replacing traditional media in terms of brand equity creation?", Management Research Review, Vol. 35 No. 9, pp. 770-790.

Bruno, S. \& Dabrowski, D. (2015), "The Impact of Brand Communication on Brand Equity Through Facebook". Journal of Research in Interactive Marketing Vol 9 No.1 pp.31-53.

Buil, I, Martinez, E, De Chernatony, L \& Martinez, E 2013, 'Examining the role of advertising

and sales promotions in brand equity creation', Journal of Business Research, Vol. 66, no.2013,

pp.115-122.

Central Agency for Public Mobilization and Statistics (CAPMAS) (2017) retrieved on feburary,18 2017 from http://www.capmas.gov.eg/

Chen, A.C. (2001). Using free association to examine the relationship between the characteristics of brand associations and brand equity. Journal of Product \& Brand Management, Vol.10 No .6/7, pp.439-449.

Christodoulides, G., Jevons, C., \& Bonhomme, J. (2012). Memo to marketers. Quantitative evidence for change: How user-generated content really affects brands? Journal of Advertising Research, Vol.52, pp.53-64.

De Chernatony, L., \& Cottam, S. (2006). Why are financial services brands not great? Journal of Product $\mathcal{E}$ Brand Management, Vol.15 No.2, pp. 88-97. 
De Chernatony, L., \& Dall'OlmoRiely, F. (1999). Experts' views about defining services brands and the principles of service branding. Journal of Business Research, Vol.32 No 11, pp.10-74.

Dimitriadis, S \& Kyrezis, N 2008, 'Does trust in the bank build trust in its technology-based

channels?', Journal of Financial Services Marketing, Vol. 13, no.1, pp. 28-38.

Duffy, D. (2005). The evolution of customer loyalty strategy. Journal of Consumer Marketing, Vol. 22 No.4/5, pp. 284-286.

E-Marketing Egypt (2017) The Internet users in Egypt Retrieved on February 13,2017

http:/ / www.emarketing-egypt.com/

eMarketer (2010). Social media in the marketing mix: Budgeting for 2011. Retrieved February 27, 2017 from http://www.scribd.com/doc/46344311/eMarketer-Social-Media-in-the-MarketingMixBudgeting-for-2011.

Fischer, E. \& Reuber, A. R. (2011) 'Social interaction via new social media: (How) can interactions on Twitter affect effectual thinking and behavior?' Journal of Business Venturing, Vol.26 pp. 1-18.

Gensler, S., Volckner, F., Liu-Thompkins, Y., \& Wiertz, C. (2013). Managing brands in the social media environment. Journal of Interactive Marketing, Vol.27, pp.242-256.

Goh, K. Y., Heng, C. S., \& Lin, Z. (2013). Social media brand community and consumer behavior: Quantifying the relative impact of user- and marketer-generated content. Information Systems Research, Vol.24 No.1, 88-107.

Gronroos, C. (2007). Services management and marketing. (3rd ed.). Chichester: John Wiley \& Sons.

Hair, JF, Black, WC, Babin, BJ \& Anderson, RE 2010, Multivariate data analysis, $7^{\text {th }}$ edn, Prentice Hall, New Jersey.

Hamann, D., William, R.L. Jr \& Omar, M. (2007), "Branding strategy and consumer high-technology product", Journal of Product \& Brand Management, Vol. 16 No. 2, pp. 98-111.

Hutter, K., Hautz, J., Dennhardt, S. and Füller, J. (2013), "The impact of user interactions in social media on brand awareness and purchase intention: the case of MINI on Facebook", Journal of Product $\mathcal{E}$ Brand Management, Vol. 22 No. 5, pp. 342-351.

Internet users around the world retrieved on March,20 2017 from

http://www.internetworldstats.com/stats1.htm

Jang, H., Olfman, L., Ko, I., Koh, J., \& Kim, K. (2008). The influence of on-line brand community characteristics on community commitment and brand loyalty. International Journal of Electronic Commerce, Vol.12 No.3, 57-80.

Keller, K.L. (1993), "Conceptualizing, measuring and managing customer-based brand equity", Journal of Marketing, Vol. 57 No. 1, pp. 1-22.

Keller, K.L. (2003), Strategic Brand Management, Prentice Hall, Upper Saddle River, NJ.

Khalid, R. (2016), Firm-created social media communication \& consumer brand perceptions; Proceedings of Academics World 18 International Conference, Boston, USA, 28 January 2016, ISBN: 978-81925751-1-7

Kietzmann, J.H., Hermkens, K., McCarthy, I.P., Silvestre, B.S. (2011). Social Media? Get Serious! Understanding the Functional Building Blocks of Social Media. Business Horizons Vol.54 No. 1, pp. 241-251

Kimpakorn, N., \& Tocquer, G. (2010). Service brand equity and employee brand commitment. Journal of Services Marketing, Vol.24 No.5 , pp. 378-388.

KPMG Africa Report 2016 retrieved on feburary, 252017 from

https://assets.kpmg.com/content/dam/kpmg/br/pdf/2016/09/fast-moving-consumer-goods.pdf

Kumar, R., Dash, S., \& Purwar, P. (2013). The nature and antecedents of brand equity and its dimensions. Journal of Marketing Intelligence and Planning, Vol.3 No.2, 141-159.

Lassar, W., Mittal, B. \& Sharma, A. (1995), "Measuring customer-based brand equity", Journal of Consumer Marketing, Vol. 12 No. 4, pp. 11-19.

Li, C. and Bernoff, J. (2011), Groundswell: Winning in a World Transformed by Social Technologies, Harvard Business Review Press, Boston, M.A. 
Lipsman, A., Mudd, G., Rich, M. \& Bruich, S. (2012), “The power of 'like': how brands reach (and influence) fans through social-media marketing", Journal of Advertising Research, Vol. 52 No. 1, pp. 40-52.

Luk, S.T., \& Yip, L.S. (2008). The moderator effect of monetary sales promotion on the relationship between brand trust and purchase behaviour. Journal of Brand Management, Vol.15 no. 6 452-464.

Mägi, A.W. (2003), "Share of wallet in retailing: the effects of customer satisfaction, loyalty cards and shopper characteristics", Journal of Retailing, Vol. 79 No. 2, pp. 97-106.

Mangold, W.G. and Faulds, D.J. (2009), "Social media: the new hybrid element of the promotion mix", Business Horizons, Vol. 52 No. 4, pp. 357-65.

Muñiz, A. M., Jr., \& Schau, H. J. (2007). Vigilante marketing and consumer-created communications. Journal of Advertising, Vol.36, pp. 35-50.

N Kaplan, A.M. and Haenlein, M. (2012), “The britney spears universe: social media and viral marketing at its best", Business Horizons, Vol. 55 No. 1, pp. 27-31.

Netemeyer, R. G., Krishnan, B., Pullig, C., Wang, G., Yagci, M., \& Dean, D. (2004). Developing and validating measures of facets of customer-based brand equity. Journal of Business Research,57(2), 209224.

Nunnally, JC \& Bernstein, IH 1994, Psychometric Theory, 3rd edn, McGraw-Hill, NewYork.

Palmatier, R.W., Scheer, L.K. and Stennkamp, J.B.E.M. (2007), “Customer loyalty to whom? Managing the bene ts and risks of salesperson-owned loyalty", Journal of Marketing Research, Vol. 44 No. 2, pp. 185199.

Prahalad, C.K.\& Ramaswamy, V., (2004) "Co-creating unique value with customers", Strategy $\mathcal{E}$ Leadership, Vol. 32 No.3, pp.4-9.

Rauyruen, P., Miller, K.E., \& Groth, M. (2009). B2B services: Linking service loyalty and brand equity. Journal of Services Marketing, Vol.23 No.3, pp.175-186.

Riegner, C. (2007), "Word of mouth on the web: the impact of Web 2.0 on consumer purchase decisions", Journal of Advertising Research, Vol. 47 No. 4, pp. 436-447.

Rios, R.E., \& Riquelme, H.E. (2008). Brand equity for online companies. Marketing Intelligence \& Planning, 26(7), pp.719-742.

Saarijärvi, H., Kannan, P.K. \& Kuusela, H. (2013) "Value co-creation: theoretical approaches and practical implications", European Business Review, Vol. 25 No. 1, pp.6-19.

Schwab, Klaus. Fourth Industrial Revolution. 1st ed. The Crown Publishing Group, 2017. Print.

Tong, X. \& Hawley, J.M. (2009), "Measuring customer based brand equity: empirical evidence from the sportswear market in China", Journal of Product \& Brand Management, Vol. 18 No. 4, pp. 262-271.

Torres, P.M., Augusto, M.G., \& Lisboa, J.V. (2015). Determining the causal relationships that affect consumer-based brand equity: The mediating effect of brand loyalty. Marketing Intelligence and Planning, 33(6), 944-956.

Tsiros, M., Mittal, V. and Ross, W.T. Jr. (2004), "The role of attributions in customer satisfaction: a reexamination", Journal of Consumer Research, Vol. 31 No. 2, pp. 476-483.

Vargo, S.L.\& Lusch, R.F. (2004) Evolving to a New Dominant Logic for Marketing. Journal of Marketing: Vol. 68, No. 1, pp. 1-17.

Vrontis, D. \& Papasolomou, I. (2007), "Brand and product building: the case of the Cyprus wine industry", Journal of Product \& Brand Management, Vol. 16 No. 3, pp. 159-167.

Xu, J.B., \& Chan, A. (2010). A conceptual framework of hotel experience and customer-based brand equity. International Journal of Contemporary Hospitability Management, 22(2), 174-193.

Yacout, O.M., \& Elsahn, M.F. (2011). Customer-based brand equity of Islamic banks in Bahrain: An empirical investigation. In Sandikci, O., \& Rice, G. (Eds.). Handbook of Islamic Marketing, UK: Edward Elgar Publishing Ltd, 274-299.

Yoo, B. \& Donthu, N. (2001), "Developing and validating a multidimensional consumer-based brand equity scale", Journal of Business Research, Vol. 52, pp. 1-14. 